\title{
The Relationship between Self-efficacy Beliefs and Autonomy among Iranian Intermediate and Upper Intermediate EFL Learners
}

\author{
Azar Mojoudi (corresponding author) \\ English department, Najafabad Branch, Islamic Azad University \\ Isfahan, Iran \\ E-mail: Mojoudi_a@yahoo.com \\ Omind Tabatabaei \\ English Department, Najafabad Branch, Islamic Azad University, Isfahan, Iran \\ E-mail: tabatabaeiomid@yahoo.com
}

Received: 10-03-2014

doi:10.7575/aiac.ijalel.v.3n.6p.22
Accepted: 10-06-2014

Published: 01-11-2014

\begin{abstract}
This study aimed to investigate the relationship between self-efficacy beliefs and autonomy among Iranian intermediate and upper intermediate EFL learners. To this end, after conducting Oxford Placement Test (OPT), 84 Iranian EFL learners at both intermediate and upper intermediate levels of English language proficiency were selected. Then, a 28item autonomy questionnaire and a 34-item self-efficacy questionnaire were administrated. In order to understand the relationship between self-efficacy and autonomy among intermediate EFL learners which is the first aim of this study, a quantitative method of data analysis procedure was conducted which falls under the category of correlational research. To do so, Pearson Correlation Coefficient was used. To figure out the same relationship between the mentioned values among upper intermediate EFL learners, the same procedure was followed. The results of the second research question indicated that there is a somehow strong correlation between the mentioned values among upper intermediate EFL learners. In addition, it was found that the mean score of the two variables is rather stronger among upper intermediate learners than the intermediate ones. At last, the findings of this study indicated that there is not a significant difference between the obtained correlation coefficients of intermediate and upper intermediate learners. By being aware of the importance of self-efficacy and autonomy in the area of language learning, and also the positive association between these values, language experts, teachers, and many learners will be guided toward the right direction in their track of teaching and learning.
\end{abstract}

Keywords: autonomy, self-efficacy beliefs, autonomous learners, motivation

\section{Introduction}

Nowadays, as the need for interaction among nations is increasing, the need for a common language for communication has been more profoundly felt. Consequently, language researchers are seeking the ways to have better language teaching and learning results. Since language learning is a lifelong journey, this process should be autonomous and learners should find out how to be autonomous because there is not always a teacher available (Quinn, 1974, cited in Yalcin Tilfarlioglu \& Seyma Ciftci, 2011).

In recent years, it has been a matter of importance for many language experts and ESL teachers to find the ways to make language learners more autonomous. It is because of the great shift in language learning and teaching approaches. During the last two decades, by exploring more communicative approaches, learners' roles have been more highlighted and teaching and learning situations have moved toward more learner-centered classrooms. As a result, learners are considered as the origin of information and researchers are seeking ways to identify the significance of training learners to be more autonomous (Yang, 1998, cited in Fahim\&Behdani, 2011).

One of the most prominent researchers in this area is Henry Holec. He defined autonomy as "the ability to take charge of one's learning" (Holec, 1981, p.3, cited in Benson \&Voller, 1997, p.1). In 1983 he defines autonomy in this way, "the learner's willingness and capacity to control or oversee his/her own learning" (Holec, 1983, cited in Thanusolus 2000, p.117). Based on Benson's 2006 point of view, autonomy can be described as "a capacity to take charge of, or take responsibility for, or control over your own learning. Form this point of view autonomy involves abilities and attitudes that people possess and can develop to various degrees" ( $\mathrm{p} .1)$

Since learner's autonomy reveals whether a person has arrived at his/her potential or not, it has become one of the prominent issues in the field of second and foreign language teaching and learning (Dafei, 2007). Regarding the importance of learner's autonomy, Sharader (2003) declares that autonomy is sometimes named as "the ABC's of learner's improvement" (p.1). In addition, Dafei (2007) states that learner's autonomy plays a part in learners' language 
proficiency. Benson (2001) avows that by entering theory and practice of language teaching and learning into a new era., guiding the learners to be autonomous in their language learning has become one of the worthwhile matters in the field of second and foreign language teaching and learning. What is clear is that an autonomous learner should be capable of planning, monitoring, managing, and reflecting on the process of language skills (Fleming \& Walls, 1998).

The mentioned concept is related to the learner's attitude to take control of language learning process and assume responsibility in this process. In order for a learner to be able to apply autonomy he/she needs to develop an understanding of the nature of language learning and of his/her role in this process and, as another component of this, to develop an appropriate repertoire of language learning strategies (White, 1995). These requirements are much the same as Wenden's conceptualization of autonomy consisting of "the use of self-instructional techniques" and "an internal change of consciousness" (1987, p.12).

The common agreement among many researchers (Benson, 2001; Dickson, 1987, 1995; Gremmo \& Riley, 1995) is that learners have to take responsibility for their learning in the learning process. The ability to take responsibility in learning process is resultant from possessing both knowledge about different learning strategies and gaining mandatory skills for exploring the best strategy choice.

Autonomy supplies the learners with some kind of beliefs and abilities to deal with a specific task in learning process. As a result, teachers in educational systems should provide some opportunities for the learners to have more responsibility in their learning process to move toward more autonomous learning.

One of the inseparable components of learners' autonomy is their self-efficacy beliefs. Bandura (1999) declares that learners' self-efficacy determines their performance since it affects their thought and motivation. It can determine their behavior as well. Bandura (2002) adds that learners' self-efficacy affects learners' psychological states and it can help the learners at different decisional points. Bandura (1981) defines self-efficacy as "people's judgment of their capabilities to organize and execute courses of action required to attain designated types of performances" (p.391).

The important point is that self-efficacy is related to learner's future capabilities in doing a specific task in a specific situation, not about his/her past achievements. Based on recent findings self-efficacy is completely a flexible concept not a rigid one (Klassen, 2004). As it is mentioned, autonomy and self-efficacy are two important concepts in the learning process. Therefore, in this study it has been tried to focus on the relationship between self-efficacy and autonomy among intermediate and upper-intermediate EFL learners.

\subsection{Statement of the problem}

Providing learners with better learning opportunities and reaching better educational results have always been crucial matters for educators and language experts. There are plenty of influential factors in this area that some have gained special importance these days. Self-efficacy and autonomy are two important elements that have caused to provide some controversy in recent years, but they have been overlooked in Iranian context especially in learning processes at different academic levels.

There are numerous studies (e.g. Magogwe \& Oliver, 2007; Yilmaz, 2010; Rahimi \& Abedini, 2009; Mango, 2009) searching for the relationship between self-efficacy and different variables such as learning strategies and proficiency, and also many studies ( e.g. Dafei, 2007; Fahim \& SheikhiBehdani, 2011; Thanasoulas, 2000) investigating the relationship between autonomy and various variables such as proficiency, critical thinking and learning; however, little attempt has been made to investigate the relationship between self-efficacy and autonomy. That is why it has been decided in this study to focus on this gap and find the relationship between self-efficacy and autonomy among Iranian intermediate and upper intermediate EFL students.

\subsection{Research Questions}

The above mentioned objectives of the study generate the following research questions:

1) Is there any significant relationship between self-efficacy and autonomy among Iranian intermediate EFL students?

2) Is there any significant relationship between self-efficacy and autonomy among Iranian upper intermediate EFL students?

\subsection{Research Hypotheses}

In order to investigate the mentioned research questions, the following null hypotheses were formulated:

$\left.\mathbf{H}_{\mathbf{0}} 1\right)$ There is no significant relationship between self-efficacy and autonomy among Iranian intermediate EFL students.

$\mathbf{H}_{\mathbf{0}}$ 2) There is no significant relationship between self-efficacy and autonomy among Iranian upper intermediate EFL students.

\subsection{Significance of the study}

Over the last decade, autonomy has become one of the controversial issues in the area of foreign and second language learning. Entering the theory and practice of language teaching into a new era and establishing learner centered teaching philosophy led to putting emphasis on helping language learners to become more autonomous in their learning process. So, learners' autonomy has become a significant matter for educationalists and language experts (Benson, 2007). Dafei (2007) states that researchers have become aware of the fact that independent self-directed learning has a great positive effect on L2 achievement. There are some affective factors in this area. Self-efficacy is considered as one of the influential factors in learning autonomy. It is an important element in forming behavior through influencing human's 
psychological states. As a result, it can motivate learners and it can be a determining factor in choosing learning strategies and hence it affects the level of learning.

Attribution and self-efficacy are considered as two types of motivators for autonomy through cognitive, motivational, affective, and decisional processes. Since self-efficacy plays a crucial role in learner autonomy and the level of learning, the present study tends to investigate the relationship between self-efficacy and autonomy among Iranian intermediate and upper intermediate students. The result of the study can have some useful pedagogical implications. Finding the relationship between self-efficacy and autonomy leads language experts to pay more attention to the results and helps them use these results for having a better educational outcome in different academic levels.

\section{Method}

\subsection{Participants}

In order to find out the relationship between self-efficacy and autonomy among Iranian intermediate and upper intermediate EFL students, a sample of 112 students contributed to this study. The participants, both male and female, were randomly selected out of 7 intact classes of intermediate and 5 intact classes of upper intermediate students in one of the institutes in Esfahan. After administrating OPT, 46 intermediate and 38 upper intermediate EFL learners consisting of 35 male and 49 female were selected. We have two almost homogeneous groups of students in terms of proficiency based on the results of their performances on OPT. Sex and age variables were not considered in this study.

\subsection{Instrumentation}

To accomplish the aims of this study, 3 types of instruments were used:

1) Oxford Placement Test( Allen, 2005)

2) The Morgan-Jinks Student Efficacy Scale (MJSES, 1999)

3) An autonomy questionnaire ( Cotterell, 2000)

The process of collecting data started with application of OPT (Allan, 2005, see appendix A) in order to select two homogenous groups of students, almost at intermediate and upper-intermediate levels. The OPT consists of 200 items including 100 grammar items. For the purpose of this study, only the grammar part was used. It took the students about 1 hour to complete the test. After administrating the test, the obtained results were estimated based on the OPT associated rating levels chart and those who received scores from 50 to 66.9 were considered as intermediate learners and those who received scores from 67 to 74 in this test were considered as upper-intermediate learners.

The second data collection tool was Morgan-Jinks Student Efficacy Scale (MJSES, 1999, see appendix B), which is a four-point Likert Scale questionnaire with the aim of determining self-efficacy beliefs of students. It has 34 items under 3 subscales which are talent, effort, and context. The students answered the questions using a four-interval scale of really agree, kind of agree, kind of disagree, and really disagree. This questionnaire has high reliability and validity. Its reliability is 0.82 and the reliability of each of its subscales is $0.78,0.66$, and 0.70 respectively. Furthermore, the word "English" was added to some of its questions to clarify the aims of the study.

The last data collection tool is an autonomy questionnaire (Cotterell, 2000, see appendix C). It is a four-point Likert Scale which was used to collect students' beliefs about autonomy. It contains several dimensions that some of them are related to this research. Four factors were selected and the obtained results were investigated. These four parts have thirty items with these titles:

1) teachers' role

2) self-efficacy

3) nature of language learning

4) strategy of language learning

The participants answered these questions on one of these alternatives:

1) strongly agree 2) agree 3) disagree 4) strongly disagree

\subsection{Procedure}

At first, two homogeneous groups of intermediate and upper intermediate learners were selected out of students through employing an OPT. The scores of selected intermediate students were from 50 to 66.9 and the upper intermediate students' scores were from 67 to 74 . Accordingly, 46 intermediate and 38 upper intermediate students were selected.

Permission was gained from institute authorities. Then the researchers distributed self-efficacy questionnaire to the students and the students answered 34 items of this four-point Likert Scale questionnaire. Finally, they responded to the items of autonomy questionnaire by choosing one of the alternatives on the four-point scale.

The researcher helped the students with the probable difficulties with the items in questionnaires, but she stuck to the detailed procedure of the administration and collecting the data of questionnaires in order not to disturb the reliability of the study. 


\subsection{Data analysis}

There are two types of variables in this study: self-efficacy and autonomy. To investigate the relationship between selfefficacy and autonomy among Iranian intermediate EFL students and also upper intermediate learners which were the aims of the first and second research questions the Pearson Correlation Coefficient procedure was utilized.

\section{Results}

\subsection{The First Research Question}

Question 1: Is there any significant relationship between self-efficacy and autonomy among Iranian intermediate EFL students?

To answer the first question, the data obtained from self-efficacy and autonomy questionnaires were processed. These data were gathered from 46 Iranian intermediate EFL students. These data, which were in qualitative format, were changed to quantitative ones ranging from 1 to 4 in order to be used in statistical process of analysis. To decipher the existence and degree of relationship between self-efficacy and autonomy at this level of proficiency, the Pearson correlation was run. The r-observed value is 0.296 a probability (two-tailed significance) of 0.046 which is less than the level of significance set for this research (0.05). As a result, it can be concluded that there is a very weak correlation between self-efficacy and autonomy among Iranian intermediate EFL learners. So, the null hypothesis predicting no significant relationship between these two variables at this level is rejected. These results are displayed in table 3.1.

Table 3.1 Correlation Coefficient between Intermediate learners' Self-Efficacy and their Autonomy

\begin{tabular}{llc}
\hline \multicolumn{3}{c}{ Autonomy } \\
\hline \multirow{4}{*}{ Self-Efficacy } & Pearson Correlation & $0.296\left(^{*}\right)$ \\
& Sig. (2-tailed) & 0.046 \\
& $\mathrm{~N}$ & 46 \\
\hline
\end{tabular}

*means the correlation coefficient is significant at .05 level

\subsection{The Second Research Question}

Question 2: Is there any significant relationship between self-efficacy and autonomy among Iranian upper intermediate EFL students?

Data collected by administering self-efficacy and autonomy questionnaires at upper intermediate level of proficiency were drawn on to answer this research question. These data were gathered from 38 Iranian upper intermediate EFL students. The same as the first question, to find the relationship between self-efficacy and autonomy this group of participants, the Pearson correlation coefficient was computed, too. The results indicate that, with the correlation coefficient of 0.536 and the probability of 0.001 , there is a somehow strong positive association between these two variables among the participants of this group. Consequently, the second null hypothesis predicting no significant relationship between self-efficacy and autonomy among upper intermediate learners was rejected.

It is worth mentioning that the common variance for this group of students is 28.7 percent.

The findings are demonstrated in table 3.2.

Table 3.2 Correlation Coefficient between upper Intermediate learners' Self-Efficacy and their Autonomy

\begin{tabular}{llc}
\hline \multicolumn{3}{c}{ Autonomy } \\
\hline \multirow{3}{*}{ Self-Efficacy } & Pearson Correlation & $0.536(*)$ \\
& Sig. (2-tailed) & 0.001 \\
& $\mathrm{~N}$ & 38 \\
\hline
\end{tabular}

*means the correlation coefficient is significant at .05 level

The next table which is table 3.3 shows the general association between self-efficacy and autonomy among EFL learners in both groups of intermediate and upper intermediate.

Table 3.3 Correlation Coefficient between both intermediate and upper Intermediate EFL learners' Self-Efficacy and their Autonomy

\begin{tabular}{llc}
\hline Atonomy & & \\
\hline \multirow{3}{*}{ Self-Efficacy } & Pearson Correlation & $0.339\left(^{*}\right)$ \\
& Sig. (2-tailed) & 0.002 \\
& $\mathrm{~N}$ & 84
\end{tabular}

*means the correlation coefficient is significant at .05 level 
As illustrated in table 3.3 there is a medium association between these two variables among intermediate and upper intermediate levels with the correlation of 0.339 and the level of probability of 0.002 .

The last table in this part consists of some statistical analyses which were done in advance in both groups to prove their acceptability for the Pearson correlation analysis to be applied to them.

Table 3.4 Kolmogorov-Smirnov test

\begin{tabular}{lllll}
\hline & upper intermediate & \multicolumn{3}{l}{ intermediate } \\
\hline & autonomy & self-efficacy & autonomy & self-efficacy \\
\hline Kolmogorov & 1.232 & 1.115 & 1.238 & 0.921 \\
\hline Asymp. Sig. (2 & 0.096 & 0.166 & 0.093 & 0.364 \\
\hline
\end{tabular}

As it is clear in table 3.4, their Asymp. levels of significance are higher than 0.05, which makes them possible to be used in the Pearson correlation analysis.

\section{Discussion}

Through investigation in literature review of language learning and previous researchers' findings, it can be inferred that there is a statistically positive relationship between students' self-efficacy and their language ability (Huang \& Schanamo, 1996; Templin, 1999; Guile \& Okuma, 2001; Anstrom, 2000). Also, review of the same literature indicated that there is a positive relationship between autonomy and language learning ability, likewise (Dafei, 2007). Consequently, self-efficacy and autonomy can be considered as two influential constructs in language learning ability.

Since learners self-efficacy has some effects on their psychological status and their thought process, it can affect their motivation, decision making, and performance in a specific action (Bandura, 1999). Considering the effects of selfefficacy on learners' performances, it can be considered as an indispensible part of learners autonomy. It was endeavored in this study to shed light on the great significance of these two variables and add another aspect to the body of existing literature about the relationship between self-efficacy and autonomy among Iranian intermediate and upper intermediate EFL learners.

In the first part of this research, by means of the results of correlational analysis, it was found that there was a very weak association between self-efficacy and autonomy among intermediate EFL learners. It means that intermediate students' autonomy increases very slightly when their self-efficacy is enhanced.

In addition, the findings revealed that there was relatively a high correlation between upper intermediate students' selfefficacy and their autonomy. This result can be interpreted in this way that when upper intermediate students selfefficacy is boosted, there will be a considerable upturn in their autonomy. Therefore, the obtained correlation for the second group (0.536) is obviously higher than that of first one (0.296). The results of data analysis in table 3.3 showed a medium correlation between these two variables with the association of 0.339 among all participants regardless of their proficiency.

In the main, it seems that the findings of this study are in line with what other researchers have obtained. Tilfarlioglu and Ciftci (2011) alert that there is a positive correlation between self-efficacy and autonomy with the correlation coefficient of $r=0.667$ and $p>0.01$. They investigated the relationship between self-efficacy and autonomy among 250 preparatory level students from some universities in Turkey. Their study unveiled that when learners self-efficacy increases, their potential to be autonomous learners enhances, as well. Although the outcomes of are somehow the same, it is clear that the magnitude of the correlations is not always the same.

Interpreting these statistics reveals that overall, EFL learners self-efficacy is linked to their autonomy. An acceptable justification for this is that since self-efficacy interacts with people's feelings and behavior, the more efficacious learners have better performance in a particular task (Bandura, 2001). Accordingly, referring to self-efficacy definition, the more efficacious learner has better judgment of his/her ability in carrying out a specific task, which leads to higher motivation and higher level of self-confidence, and consequently, a higher level of autonomy. In other words, efficacious learners set challenging goals for themselves and endeavor to accomplish these goals (Bandura, 1997b). As they believe in their capability in doing this and are confident of their accomplishment, they boost their confidence which leads to more self-directed or autonomous learners.

These claims are also in accordance with Schmenk (2005) assertions. Schmenk (2005) asserts that self-efficacy is a prerequisite for learner autonomy for they can control their own learning and take responsibility in this issue when they become aware of their abilities.

\section{Conclusion}

These years, many researchers have concentrated on some psychological concepts that play an influential role in language learning. Self-efficacy and autonomy, which have attracted many language experts including Dafei, Cotteral, Bandura, Thanasolus and etc, are among crucial concepts in this area. In this study, it was tried to display the relationship between self-efficacy and autonomy among Iranian intermediate and upper intermediate EFL learners. The findings of the study can provide pedagogical implication in Iranian context. 
The subjects of the study were 84 intermediate and upper intermediate EFL students of an institute in Esfahan. By means of two self-efficacy and autonomy questionnaires, the researcher's data were gathered. Correlational analysis was run on the collected data to discover the relationship between the mentioned values for the targeted two levels of proficiency. The results of the study indicate that, with the correlation coefficient of 0.339 , there is a moderate association between these two constructs among all participants in both groups in general. In addition, it was found that there is a very weak correlation $(\mathrm{r}=0.296)$ between these concepts among Iranian intermediate EFL learners. On the other hand, the results of the study unveil a somehow strong association between the values at upper intermediate level. Accordingly, the more efficacious the learners are, the more autonomous they become to some extent.

\section{References}

Anstrom, K. (2000). High school foreign language students' perceptions of language learning strategy use and selfefficacy.Washington, D.C. National Foreign Language Resource Center, Georgetown University/Center for Applied Linguistics.

Bandura, A. (1981). Self-referent thought: A developmental analysis of self-efficacy. In J. H. Flavel,\& L. Ross Ed.), Social cognitive development: Frontiers and possible futures (pp. 200-230). Cambridge, England: Cambridge University Press.

Bandura, A. (1997b). Self-efficacy.Harvard Mental Health Letter, 13(9) 4-6.

Bandura, A. (1999). A social cognitive theoryof personality. In L.Pervin \& O.John (Eds), Handbook of personality (2 ${ }^{\text {nd }}$ ed., pp. 154-196). New York: Guilford

Bandura, A. (2001). Guide for constructing self-efficacy scales. Stanford, CA, USA: Stanford University.

Bandura, A. (2002). Social cognitive theory in cultural context. Journal of Applied Psychology: An International Review, 51, 269-290.

Benson, P. (2001). Teaching and researching autonomy in language learning. London: Longman, 47.

Benson, P. (2007). Autonomy in language teaching and learning. State of the Art Article. Language Teaching, 40, 1: 21-40.

Benson, P. \& P. Voller (eds.) (1997). Autonomy and independence in language learning. London: Longman.

Cotterall, S. 1999. Key Variables in Language Learning: What do Learners Believe about Them? System, 27 (1), pp. 493-513.

Dafei, D. (2007). An exploration of the relationship between learner autonomy and English proficiency. Asian EFL Journal, 1-23.

Dickinson, L. (1987). Self-instruction in language learning. Cambridge: Cambridge University Press.

Dickinson, L. (1995). Autonomy and motivation: A literature review. System 23.2, 165-174.

Fahim.M. and Behdani.R.(2011). Critical Thinking Ability and Autonomy of Iranian EFL Learners. American Journal of Scientific ResearchISSN 1450- 223X,29(2011),59-72.

Fleming, F. \& G. Walls, 1998. What pupils do: The role of strategic planning in modern foreign language learning. Language Learning Journal, 18: 14-21. Templin, S. A. (1999). The Relationship between Self-Efficacy and Language Learners' Grades .JALT Journal 21(1).112-121.

Gremmo, M-J. \& P. Riley (1995). Autonomy, self-direction and self-access in language teaching and learning: The history of an idea. System 23.2, 151-164.

Huang, S. C., \&Shanmao, C. F. (1996).Self-efficacy of English as a Second Language Learner: An example of four learners. ERIC Document Reproduction Service No. ED 396536.

Klassen, R. M. (2004). Optimism and realism: a review of self-efficacy from a cross-cultural perspective. International Journal of Psychology, 39 (3), 205-230.

Magogwe, J. M., Oliver, R. (2007). The relationship between language learning strategies, proficiency, age and selfefficacy beliefs: A study of language learners in Botswana. System, 35, 338-352.

Mango C., (2009).Investigating the Effect of School Ability on Self-efficacy, Learning Approaches, and Metacognition.The Asia-Pacific Education Researcher, 18:2, pp. 233-244.

Rahimi, A., \&Abedini, A. (2009).The interface between EFL learners' self-efficacy concerning listening comprehension and listening proficiency.Novitas Royal, 3(1), 14-28.

Schmenk, B. (2005). Globalizing learner autonomy. TESOL Quarterly 39.1, 107-118.

Shrader, S.R., 2003, 'Learner Empowerment-A Perspective', The Internet TESL Journal 9(11), November, available at http://iteslj.org/Articles/Shrader-Empowerment.html, accessed 13 July 2012.

Templin, S. A., Guile, T. C., \& Okuma, T. (2001). Creating a reliable and valid self-efficacy questionnaire and English test to raise learners $L 2$ achievement via raising their self-efficacy.Retrieved April, 2012 from http://www.eric.ed.gov. 
Thanasoulas, D. (2000). What is learner autonomy and how can it be fostered? The Internet TESL Journal 11. http://iteslj.org/Articles/Thanasoulas-Autonomy.html accessed 7/9/2006.

Wenden, A. L (1987). Metacognition: An expanded view on the cognitive abilities of L2 learners. Language Leaming, 37 (4), 573-598.

Wenden, A. (1991). Learner strategies for learner autonomy. New York: Prentice Hall.

White, C. (1999). Expectations and emergent beliefs of self-instructed language learners. System, 27(4), $443-457$.

YalcinTilfarlioglu, F. \& Seyma Ciftci, F. (2011). Supporting self-efficacy and learner autonomy in relation to academic success in EFL classrooms( a case study). Theory and Practice in Laguage Studies, 1(10), 1284-1294.

Yilmaz, C.(2010). The relationship between language learning strategies, gender, proficiency and self-efficacy beliefs: a study of ELT learners in Turkey. Procedia Social and Behavioral Science, 2, 682-687. 